\title{
MOBILE APP EDUCATION GANGGUAN PENCERNAAN MANUSIA BERBASIS MULTIMEDIA MENGGUNAKAN ADOBE ANIMATE CC
}

\author{
Samsudin ${ }^{1}$, Muhammad Dedi Irawan ${ }^{2}$, Ahmad Hariandy Harahap ${ }^{3}$ \\ Program Studi Sistem Informasi, Universitas Islam Negeri Sumatera Utara \\ Jl. IAIN, Medan, Universitas Islam Negeri Sumatera Utara \\ mr.samsudin@gmail.com ${ }^{1}$, muhammaddediirawan@uinsu.com² ,hariandy0817@ gmail.com $^{3}$
}

\begin{abstract}
Technological progress is changing very rapidly from year to year, mobile devices are one of the fastest growing technological products in its development, with the development of cellular technology at this time, which causes many changes, including in the world of education. Using mobile applications as learning tools can benefit from the availability of learning material that can be accessed at any time, and visualization of interesting material. the problem that arises is the lack of time for communication between teacher and students and learning that is still used by the media of books, which are mainly presented in the form of text, making students less attractive for further lessons. Therefore, researchers have developed educational applications to increase student motivation. Adobe Animate CC software is used to develop mobile multimedia applications to teach the human digestive system and multimedia disorders, this application is intended as an alternative source of student learning, so this application stimulates student motivation so students can play and learn on their own in their free time.
\end{abstract}

Keywords - Mobile App, Learning Media, Human Digestive System, Multimedia, Adobe Animate CC

Abstract - Kemajuan teknologi berubah sangat cepat dari tahun ke tahun, perangkat seluler adalah salah satu produk teknologi yang tumbuh paling cepat dalam perkembangannya, dengan perkembangan teknologi seluler saat ini, yang menyebabkan banyak perubahan, termasuk di dunia pendidikan. Menggunakan aplikasi seluler sebagai alat pembelajaran dapat mengambil manfaat dari ketersediaan materi pembelajaran yang dapat diakses kapan saja, dan visualisasi materi yang menarik. masalah yang muncul adalah kurangnya waktu untuk komunikasi antara guru dan siswa dan pembelajaran yang masih menggunakan oleh media buku, yang terutama disajikan dalam bentuk teks, membuat siswa kurang menarik untuk pelajaran selanjutnya. Oleh karena itu, peneliti telah mengembangkan aplikasi edukasi untuk meningkatkan motivasi siswa. Perangkat lunak Adobe Animate CC digunakan untuk mengembangkan aplikasi multimedia bergerak untuk mengajar sistem pencernaan manusia dan gangguan multimedia, aplikasi ini dimaksudkan sebagai alternatif sumber belajar siswa, sehingga aplikasi ini merangsang motivasi siswa agar siswa dapat bermain dan belajar sendiri pada waktu luang mereka.

Kata Kunci - Mobile App, Media Pembelajaran, Sistem Pencernaan Manusia, Multimedia, Adobe Animate CC

\section{PENDAHULUAN}

Kemajuan teknologi telah berubah dengan sangat cepat dari tahun ke tahun, perangkat seluler adalah salah satu produk teknologi tercepat dalam perkembangannya, sehingga perangkat seluler secara bersamaan melakukan berbagai fungsi. Tidak hanya sebagai alat komunikasi, tetapi juga berubah menjadi alat dengan fungsi lain, seperti media hiburan, media pendidikan, media bisnis, dan mampu meluncurkan aplikasi mobile dengan berbagai format sehingga dapat digunakan di mana saja.

Dengan perkembangan teknologi mobile, banyak perubahan yang terjadi saat ini, termasuk di dunia pendidikan. Menggunakan aplikasi seluler sebagai alat pembelajaran dapat mengambil manfaat dari ketersediaan materi ajar yang dapat diakses kapan saja, dan visualisasi materi yang menarik. Aplikasi mobile adalah alat pembelajaran alternatif yang memungkinkan siswa untuk mengambil pelajaran dengan cepat [1]. Diharapkan media pembelajaran yang dikemas dalam aplikasi mobile akan lebih beragam dan inovatif sehingga proses pembelajaran dapat dilakukan dengan lebih efisien dan efektif..

Sistem pencernaan manusia adalah salah satu pelajaran yang dibahas di sekolah khususnya pada materi biologi, terutama di tingkat sekolah menengah atas kelas XI. Sistem pencernaan manusia adalah sistem yang terdiri dari organ-organ pencernaan yang berfungsi untuk mencerna makanan dalam tubuh manusia, termasuk mulut, kerongkongan, lambung, hati, usus kecil, usus besar dan anus. Proses-proses yang dilakukan di sekolah masih tradisional, yaitu pembelajaran dengan bertatap muka, yang biasanya dilakukan antara guru dan siswa di ruang kelas atau di laboratorium. Waktu yang guru dan siswa dapat bertemu tatap muka di ruang kelas dan laboratorium sangat terbatas. Selain itu, proses penyampaian materi masih dipelajari menggunakan media buku, yang sebagian besar disajikan dalam bentuk teks, yang 
membuat siswa kurang menarik untuk pelajaran berikutnya. Oleh karena itu, aplikasi edukasi untuk melatih sistem pencernaan manusia dan gangguannya merupakan solusi yang memungkinkan guru memberikan pelajaran dengan media yang berbeda yaitu aplikasi mobile. Menggunakan aplikasi mobile, proses pendidikan dapat dilakukan pada jam sekolah ataupun diluar jam sekolah. Selain itu, aplikasi ini dibuat menarik dan tidak monoton bagi siswa, karena merupakan aplikasi multimedia dengan tampilan teks, suara, gambar, animasi dan video. Dengan membuat aplikasi ini, diharapkan pelajaran dari sistem pencernaan manusia akan lebih mudah dipelajari di mana saja dengan menggunakan perangkat seluler.

\section{A. Aplikasi Mobile}

Aplikasi seluler adalah aplikasi yang dirancang khusus untuk platform seluler (mis. IOS, Android atau Windows Mobile). Dalam beberapa kasus, aplikasi seluler menyediakan mekanisme interaksi antar muka yang unik, interaksi dengan sumber daya web yang menyediakan akses ke berbagai informasi terkait aplikasi, dan kemampuan pemrosesan lokal untuk mengumpulkan, menganalisis, dan memformat informasi sehingga lebih baik untuk platform seluler. Selain itu, aplikasi seluler menyediakan kemampuan penyimpanan permanen di platform.

Melalui penggunaan aplikasi seluler, kita dapat dengan mudah melakukan berbagai kegiatan mulai dari belajar, hiburan, penjualan, navigasi, dll. Aplikasi mobile banyak digunakan untuk hiburan, karena dengan menggunakan fungsi permainan, pemutar musik dan pemutar video, lebih mudah bagi kita untuk menikmati hiburan kapan saja, di mana saja[2].

\section{B. Media Pembelajaran}

Media adalah cara mentransmisikan pesan / informasi yang dapat ditransmisikan ke penerima informasi menggunakan berbagai alat / teknologi yang mempengaruhi penambahan pengetahuan, keterampilan dan perubahan dalam hubungannya dengan seseorang. Alat pengajaran adalah metode yang digunakan oleh guru untuk memberikan informasi kepada siswa dalam bentuk materi menggunakan berbagai alat / teknologi yang memudahkan siswa untuk menangkap konten materi dan menambahkan pengetahuan, keterampilan, dan perubahan pada siswa tersebut [3].

\section{Metode Waterfall}

Metode Waterfall adalah siklus pengembangan aplikasi yang mencakup prosedur dan langkah-langkah yang secara teknis memandu proyek dari awal hingga selesai. Secara umum, tahapan dibagi menjadi empat jenis kegiatan utama, yaitu: analisis, desain, implementasi, dan pemeliharaan. Perangkat lunak yang dikembangkan berdasarkan SDLC akan menghasilkan sistem berkualitas tinggi, memenuhi harapan pengguna, tepat waktu dan biaya, bekerja secara efisien dan efektif dalam infrastruktur teknologi informasi yang ada atau yang direncanakan, dan akan mudah untuk mempertahankan dan mengembangkan lebih lanjut [2].

Fase-fase dalam Metode Waterfall menurut Pressman[2]:

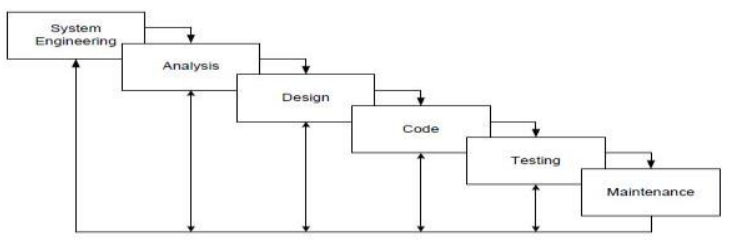

Gambar 1. Fase-fase Metode Waterfall

\section{Unified Model Language (UML)}

UML merupakan alat yang digunakan untuk mendukung pengembangan perangkat lunak berbasis objek. Alat bantu yang digunakan dalam perancangan berorientasi objek berbasiskan UML yaitu usecase diagram, activity diagram, sequensial diagram, class diagram dan lain sebagainya [4][5].

\section{E. Adobe Animate CC}

Adobe Animate $\mathrm{CC}$ adalah program yang dikembangkan secara khusus oleh Adobe dan program aplikasi standar untuk alat pengembangan profesional yang digunakan untuk membuat animasi dan bitmap yang sangat menarik untuk membuat situs web yang interaktif dan dinamis. Flash dirancang dengan kemampuan untuk membuat animasi dua dimensi yang kuat dan ringan, sehingga Flash banyak digunakan untuk membuat dan memberikan efek animasi pada situs web, CD interaktif, dan lainnya[6]

Adobe AIR for Android adalah salah satu menu tambahan di Adobe Flash CS6 dan Adobe Animate CC. Di mana Adobe Flash adalah produk unggulan dari Adobe Systems. Adobe Flash sebelumnya bernama Macromedia Flash. Adobe Flash CS6 dan Adobe Animate CC adalah aplikasi yang kuat untuk membuat konten animasi dan multimedia. Buat antarmuka interaktif terperinci yang akan disajikan pada komputer desktop dan beberapa program, termasuk tablet, ponsel cerdas, dan televisi.

\section{F. Multimedia Interaktif}

Multimedia interaktif adalah sistem presentasi yang menggunakan aplikasi komputer yang menggabungkan berbagai aplikasi visual dan audiovisual dan dikendalikan secara interaktif menggunakan aplikasi kontrol untuk memastikan kemudahan penggunaan saat memproses atau mencari 
informasi yang diperlukan secara berurutan atau secara acak melalui sistem navigasi logis interaktif [7]

Interaktif berarti keterlibatan bersama. Ini berarti bahwa ada hubungan timbal balik antara pengguna (pengguna) dan media (program), pengguna menanggapi permintaan / pandangan media (program) dan kemudian melanjutkan untuk menyajikan informasi / konsep yang kemudian disajikan oleh media ( program)[8]

\section{METODE PENELITIAN}

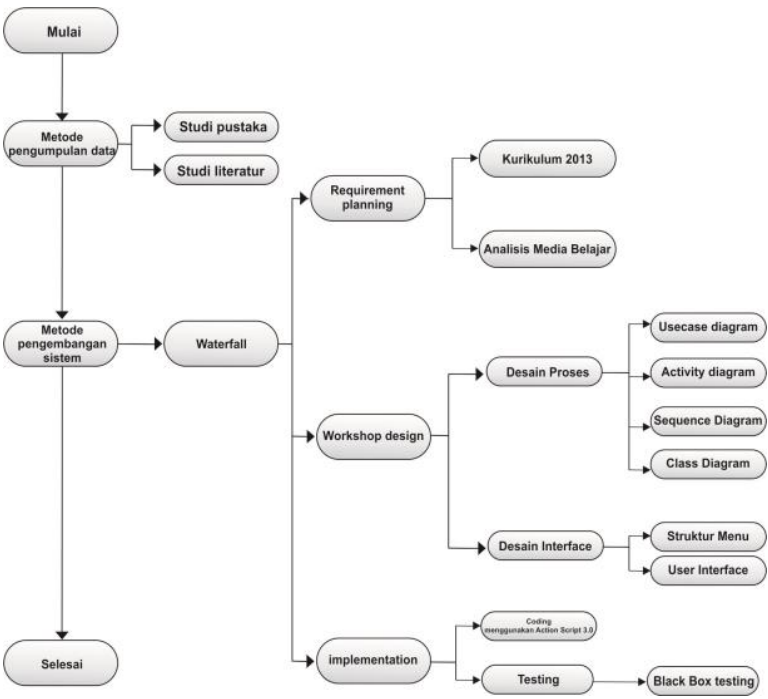

Gambar 2. Kerangka Penelitian

Bagian ini menjelaskan kerangka penelitian yang ditunjukan oleh gambar 2. Adapun penelitian ini dilakukan dalam 2 metode yaitu Metode pengumpulan data dan metode pengembangan sistem. (1) Metode pengumpulan data diantaranya adalah studi pustaka dan studi literatur untuk mendapatkan informasi mengenai kebutuhan aplikasi. (2) Metode pengembangan sistem menggunakan metode waterfall, metode ini memiliki tahapan-tahapan proses diantaranya analisis kebutuhan, pendesain aplikasi, implementasi, testing dan maintenence.

\section{HASIL DAN PEMBAHASAN}

\section{A. Analisis}

1. Analisis Kebutuhan

Tahap analisis kebutuhan dilakukan dengan menganalisa kebutuhan user, analisa data, perangkat lunak dan perangkat keras yang dibutuhkan dalam pengembangan sistem serta kebutuhan lainnya.

a. Data

Pada tahap ini, penulis akan mencari data dan informasi yang bersumber dari buku, jurnal dan penelitian-penelitian yang berkaitan dengan materi penelitian kurikulum 2013 dan media belajar. b. Perangkat Keras (hardware)

Perangkat Keras (hardware) yang digunakan dalam penelitian ini adalah laptop dengan spesifikasi sebagai berikut:

1. Processor Intel $\AA$ Core Co $^{\mathrm{TM}} \mathrm{i} 3-60060$

2. RAM 4 GB DDR3

3. Harddisk $500 \mathrm{~GB}$

4. Layar 14" resolusi $1366 \times 768$ pixels

c. Perangkat Lunak (software)

Perangkat lunak (software) yang digunakan dalam penelitian ini adalah sebagai berikut:

1. Sistem Operasi Windows 10 64-bit

2. Adobe Animate CC

3. Corel Draw X7

4. Mendeley Desktop versi 1.19.4

5. Microsoft Visio 2013

\section{Analisis Kurikulum Materi}

Analisis yang dilakukan peneliti sebelum mengembangkan media pembelajaran dilakukan dengan cara mengkaji kurikulum tentang standar kompetensi inti dan kompetensi dasar.

\section{Analisis Media Belajar}

Media belajar atau alat belajar yang digunakan perlu dianalisis sesuai dengan kebutuhan siswa. Fenomena yang terjadi media yang digunakan masih konvensional dengan media cetak seperti buku, lks, dan buku lainnya. Maka dari media konvensional tersebut siswa akan merasa bosan dan kurangnya motivasi dalam belajar.

Dengan demikian peneliti berasumsi bahwa penerapan perangkat mobile sebagai media pembelajaran yang interaktif dapat digunakan siswa sebagai alternatif sumber belajar yang dapat dijalankan pada perangkat android.

\section{B. Desain}

1. Desain Proses

Pada tahap ini, proses desain sistem yang diusulkan akan dijelaskan menggunakan bahasa pemodelan terpadu (UML), yaitu: menggunakan diagram kasus (usecase) untuk menggambarkan hubungan antara aktor dan sistem yang sedang dibuat, diagram tindakan(activity) untuk menjelaskan aliran tindakan dengan sistem, urutan diagram(sequence) untuk menggambarkan objek melalui pesan, untuk menunjukkan hubungan antar kelas.

\section{a. Use Case Diagram}

Usecase Diagram adalah diagram yang dibuat untuk menggambarkan hubungan faktor-faktor yang terlibat dalam membuat aplikasi.. 


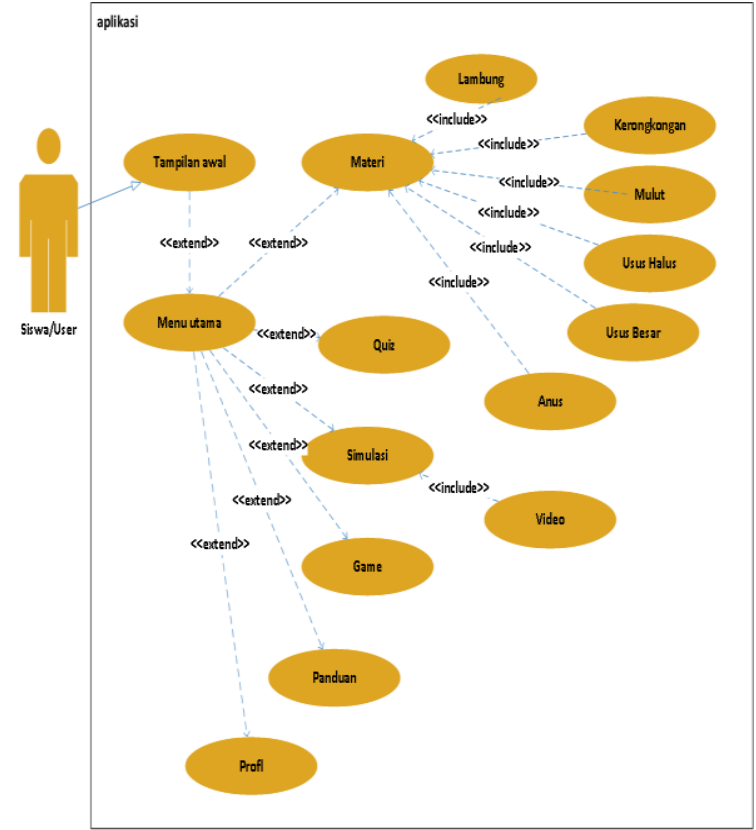

Gambar 3. Use Case Diagram

\section{b. Class Diagram}

Class Diagram mendeskripsikan jenis-jenis objek dalam sistem dan berbagai macam hubungan statis yang terdapat diantara mereka. Class Diagram juga menunjukkan properti dan operasi sebuah class dan batasan-batasan yang terdapat dalam hubunganhubungan objek tersebut. Class diagram membangun aplikasi Mobile media pembelajaran berbasis multimedia sebagai berikut:

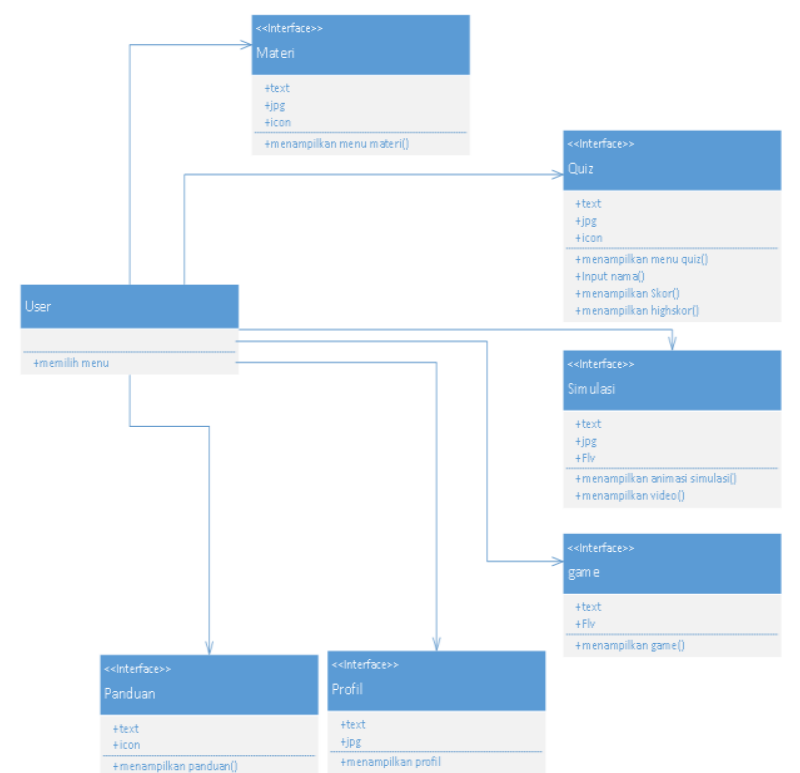

Gambar 4. Class Diagram

\section{c. Activity Diagram}

Activity diagram adalah salah satu cara untuk memodelkan event-event yang terjadi dalam suatu $U s e$ Case. Berikut ini activity diagram dari Aplikasi Mobile
Media Pembelajaran Sistem Pencernaan Manusia dan Gangguannya berbasis Multimedia untuk user:

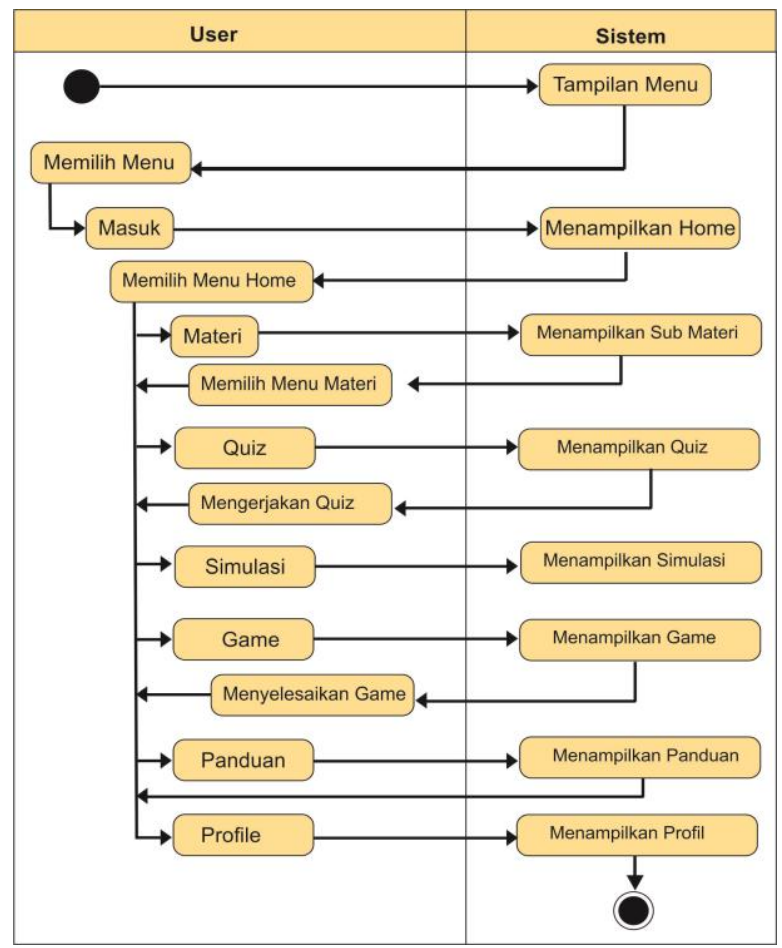

Gambar 5. Activity Diagram

\section{d. Sequence Diagram}

Sequence Diagram adalah suatu diagram yang menggambarkan interaksi antar obyek dan mengindikasikan komunikasi Siantar obyek-obyek tersebut. Berikut Sequence Diagram Aplikasi Mobile Media Pembelajaran Sistem Pencernaan Manusia dan Gangguannya Berbasis Multimedia:

\section{1) Sequence Diagram Menu Materi}

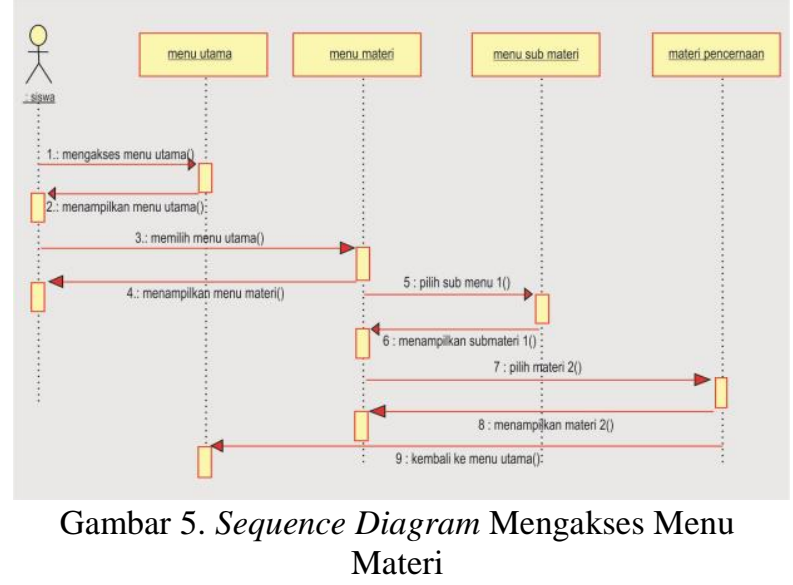


2) Sequence Diagram Menu Quiz

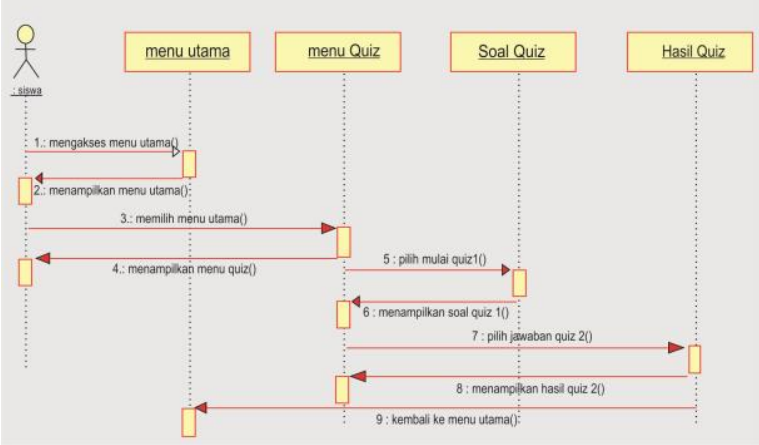

Gambar 6. Sequence Diagram Mengakses Menu Quiz

3) Sequence Diagram Menu Simulasi

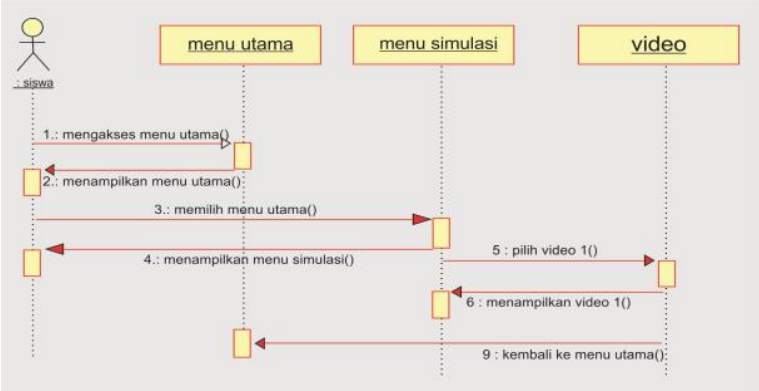

Gambar 7. Sequence Diagram Mengakses Menu Simulasi

4) Sequence Diagram Menu Game

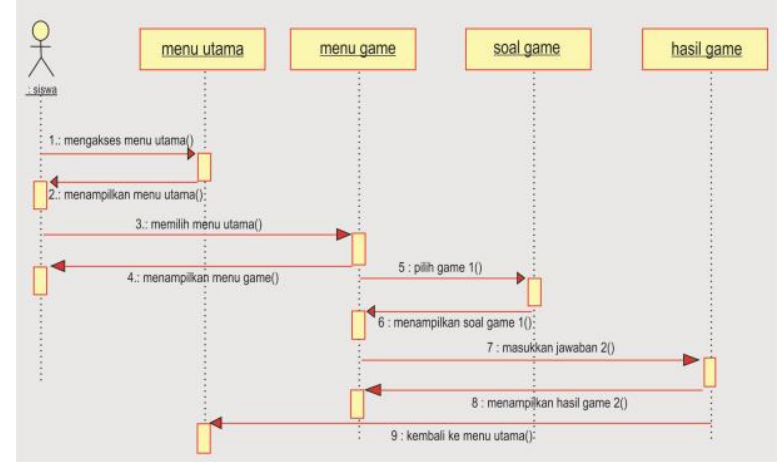

Gambar 8. Sequence Diagram Mengakses Menu Game

2. Storyboard

Tabel 6. Storyboard

\begin{tabular}{|c|c|c|c|c|}
\hline No & Halaman & Isi Tampilan & $\begin{array}{l}\text { Tombol } \\
\text { Navigasi }\end{array}$ & $\begin{array}{l}\text { Gambar/S } \\
\text { uara/Anim } \\
\text { asi }\end{array}$ \\
\hline 1. & $\begin{array}{l}\text { Tampilan } \\
\text { Awal }\end{array}$ & $\begin{array}{l}\text { Animasi } \\
\text { "Sistem } \\
\text { Pencernaan } \\
\text { Manusia } \\
\text { Media } \\
\text { Pembelajaran } \\
\text { " }\end{array}$ & $\begin{array}{l}\text { Tombol } \\
\text { Masuk } \\
\text { Tombol } \\
\text { Backsound } \\
\text { On/Off } \\
\text { Tombol } \\
\text { Exit }\end{array}$ & $\begin{array}{l}\text { Gambar } \\
\text { Animasi } \\
\text { Backsound }\end{array}$ \\
\hline
\end{tabular}

\begin{tabular}{|c|c|c|c|c|}
\hline No & Halaman & Isi Tampilan & $\begin{array}{l}\text { Tombol } \\
\text { Navigasi }\end{array}$ & $\begin{array}{l}\text { Gambar/S } \\
\text { uara/Anim } \\
\text { asi }\end{array}$ \\
\hline 2. & $\begin{array}{l}\text { Menu } \\
\text { Utama }\end{array}$ & $\begin{array}{l}\text { Menu Materi } \\
\text { Menu Quiz } \\
\text { Menu } \\
\text { Simulasi } \\
\text { Menu Game } \\
\text { Menu } \\
\text { Panduan } \\
\text { Menu Profil }\end{array}$ & $\begin{array}{l}\text { Tombol } \\
\text { Materi } \\
\text { Tombol } \\
\text { Quiz } \\
\text { Tombol } \\
\text { Simulasi } \\
\text { Tombol } \\
\text { Game } \\
\text { Tombol } \\
\text { Panduan } \\
\text { Tombol } \\
\text { Profil } \\
\text { Tombol } \\
\text { Backsound } \\
\text { On/Off } \\
\text { Tombol } \\
\text { Exit }\end{array}$ & $\begin{array}{l}\text { Gambar } \\
\text { Animasi } \\
\text { Backsound } \\
\text { Backgroun } \\
d \\
\text { Suara } \\
\text { Tombol }\end{array}$ \\
\hline 3. & $\begin{array}{l}\text { Menu } \\
\text { Materi }\end{array}$ & $\begin{array}{l}\text { Menu Rongga } \\
\text { Mulut } \\
\text { Menu } \\
\text { Kerongkonga } \\
\text { Menu } \\
\text { Lambung } \\
\text { Menu Usus } \\
\text { Halus } \\
\text { Menu Usus } \\
\text { Besar } \\
\text { Menu Anus }\end{array}$ & $\begin{array}{l}\text { Tombol } \\
\text { Rongga } \\
\text { Mulut } \\
\text { Tombol } \\
\text { Kerongkon } \\
\text { gan } \\
\text { Tombol } \\
\text { Lambung } \\
\text { Tombol } \\
\text { Usus Halus } \\
\text { Tombol } \\
\text { Usus Besar } \\
\text { Tombol } \\
\text { Anus } \\
\text { Tombol } \\
\text { Kembali ke } \\
\text { Menu } \\
\text { Utama } \\
\text { Tombol } \\
\text { Backsound } \\
\text { On/Off } \\
\text { Tombol } \\
\text { Exit }\end{array}$ & $\begin{array}{l}\text { Backsound } \\
\text { Backgroun } \\
d \\
\text { Suara } \\
\text { Tombol } \\
\text { Gambar } \\
\text { Materi }\end{array}$ \\
\hline 4. & $\begin{array}{l}\text { Menu } \\
\text { Quiz }\end{array}$ & $\begin{array}{l}\text { Header } \\
\text { Input nama } \\
\text { Soal Quiz } \\
\text { Hasil Quiz }\end{array}$ & $\begin{array}{l}\text { Tombol } \\
\text { Mulai } \\
\text { Option } \\
\text { Jawaban } \\
\text { Next soal } \\
\text { Kembali ke } \\
\text { menu } \\
\text { utama }\end{array}$ & $\begin{array}{l}\text { Backsound } \\
\text { Backgroun } \\
d \\
\text { Suara } \\
\text { Tombol } \\
\text { Gambar } \\
\text { jawaban } \\
\text { benar/salah }\end{array}$ \\
\hline 5. & $\begin{array}{l}\text { Menu } \\
\text { Simulasi }\end{array}$ & $\begin{array}{l}\text { Header } \\
\text { Animasi } \\
\text { "proses } \\
\text { makanan }\end{array}$ & $\begin{array}{l}\text { Tombol } \\
\text { video }\end{array}$ & $\begin{array}{l}\text { Backsound } \\
\text { Backgroun } \\
d\end{array}$ \\
\hline
\end{tabular}




\begin{tabular}{|c|c|c|c|c|}
\hline No & Halaman & Isi Tampilan & $\begin{array}{l}\text { Tombol } \\
\text { Navigasi }\end{array}$ & $\begin{array}{l}\text { Gambar/S } \\
\text { uara/Anim } \\
\text { asi }\end{array}$ \\
\hline & & $\begin{array}{l}\text { masuk ke } \\
\text { tubuh" } \\
\text { Video } \\
\text { pembelajaran }\end{array}$ & $\begin{array}{l}\text { Kembali ke } \\
\text { menu } \\
\text { utama }\end{array}$ & $\begin{array}{l}\text { Suara } \\
\text { Tombol }\end{array}$ \\
\hline 6. & $\begin{array}{l}\text { Menu } \\
\text { Game }\end{array}$ & $\begin{array}{l}\text { Header } \\
\text { Soal Game } \\
\text { Hasil game }\end{array}$ & $\begin{array}{l}\text { Masukkan } \\
\text { jawaban } \\
\text { game } \\
\text { Kembali ke } \\
\text { menu } \\
\text { utama }\end{array}$ & $\begin{array}{l}\text { Backsound } \\
\text { Backgroun } \\
d \\
\text { Suara } \\
\text { Tombol } \\
\text { Gambar } \\
\text { jawaban } \\
\text { benar/salah }\end{array}$ \\
\hline 7. & $\begin{array}{l}\text { Menu } \\
\text { Panduan }\end{array}$ & $\begin{array}{l}\text { Header } \\
\text { panduan } \\
\text { penggunaan } \\
\text { aplikasi }\end{array}$ & $\begin{array}{l}\text { Kembali ke } \\
\text { menu } \\
\text { utama }\end{array}$ & $\begin{array}{l}\text { Backsound } \\
\text { Backgroun } \\
d \\
\text { Suara } \\
\text { Tombol }\end{array}$ \\
\hline 8. & $\begin{array}{l}\text { Menu } \\
\text { Profil }\end{array}$ & $\begin{array}{l}\text { Header } \\
\text { Informasi } \\
\text { profil } \\
\text { pengembang }\end{array}$ & $\begin{array}{l}\text { Kembali ke } \\
\text { menu } \\
\text { utama }\end{array}$ & $\begin{array}{l}\text { Animasi } \\
\text { teks } \\
\text { Backsound } \\
\text { Backgroun } \\
d \\
\text { Suara } \\
\text { Tombol } \\
\end{array}$ \\
\hline
\end{tabular}

\section{Implementasi}

Dalam membangun sebuah sistem yang telah didesain perlu dibuat implementasi. Implementasi berguna sebagai pengujian atau tolak ukur dan analisa hasil dari sistem yang telah dibuat. Implementasi sistem merupakan proses pembuatan dan penerapan sistem secara keseluruhan dari sisi perangkat lunak maupun perangkat kerasnya.

\section{Tampilan Aplikasi}

Berikut ini adalah tampilan dari implementasi program keseluruhan yang telah dirancang yaitu sebagai berikut:

a. Tampilan Awal

Tampilan awal merupakan tampilan saat pertama kali aplikasi dijalankan dimana akan terdapat tombol masuk untuk menampilkan menu utama.

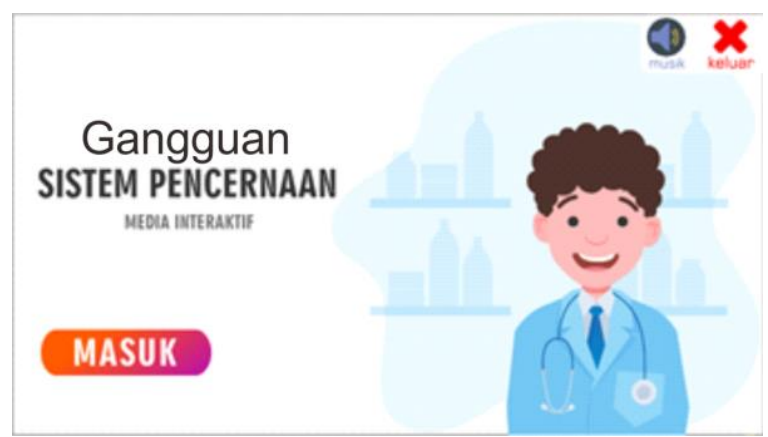

Gambar 9. Tampilan Halaman Awal

\section{b. Menu Utama}

Menu utama merupakan halaman menu yang akan menampilkan beberapa tombol pilihan yang dapat dipilih user.

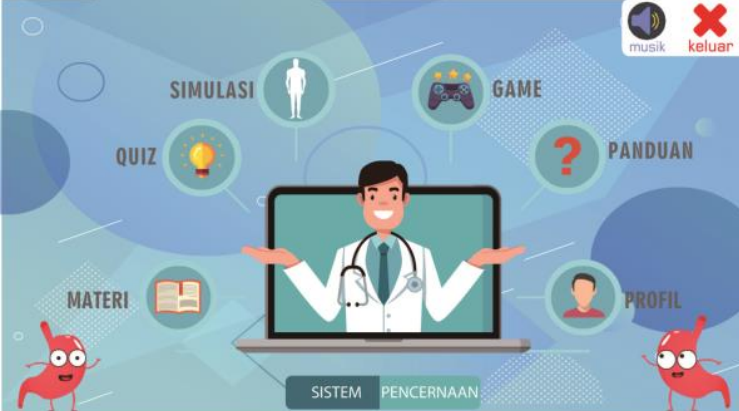

Gambar 10. Tampilan Menu Utama1

c. Menu Materi

Menu materi adalah halaman yang berisi materi tentang sistem pencernaan manusia dan gangguannya yang akan dibahas mulai dari rongga mulut, kerongkongan, lambung, usus dua belas jari, usus besar dan anus.

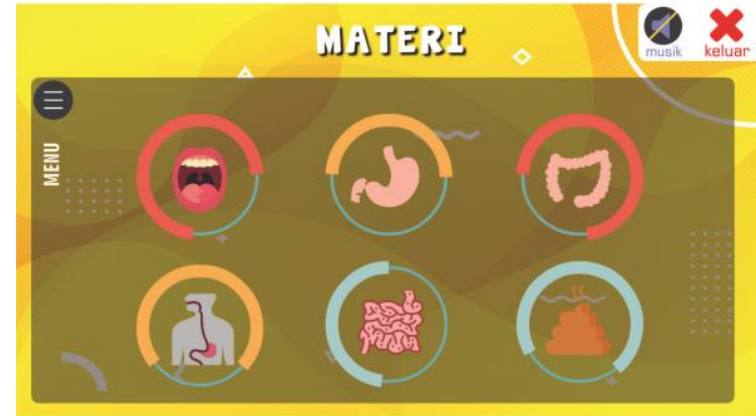

Gambar 11. Tampilan Menu Materi

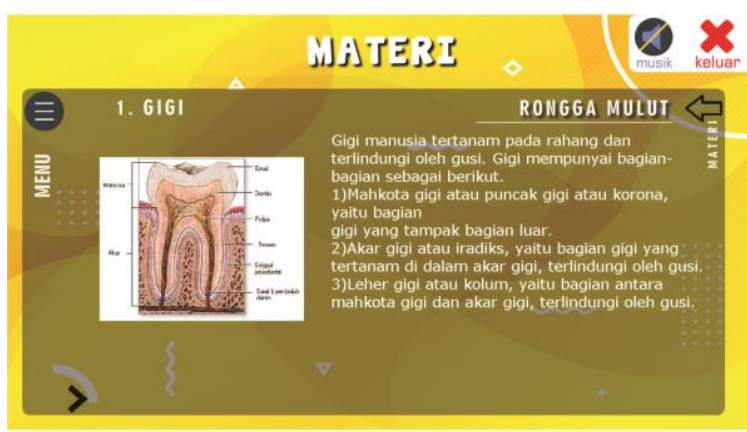

Gambar 12. Tampilan Salah Satu Materi Sistem Pencernaan Manusia

\section{d. Menu Quiz}

Menu kuis adalah halaman yang berisi pertanyaan pilihan ganda dan disertai dengan skor penilaian dan waktu dalam menjawab soal. 


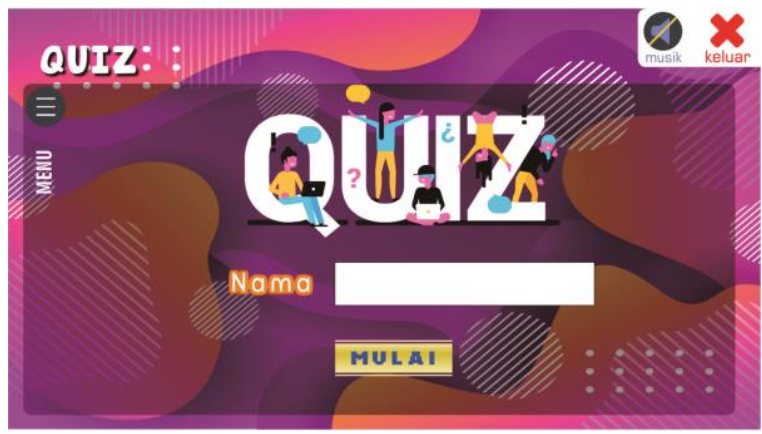

Gambar 13. Tampilan Menu Materi

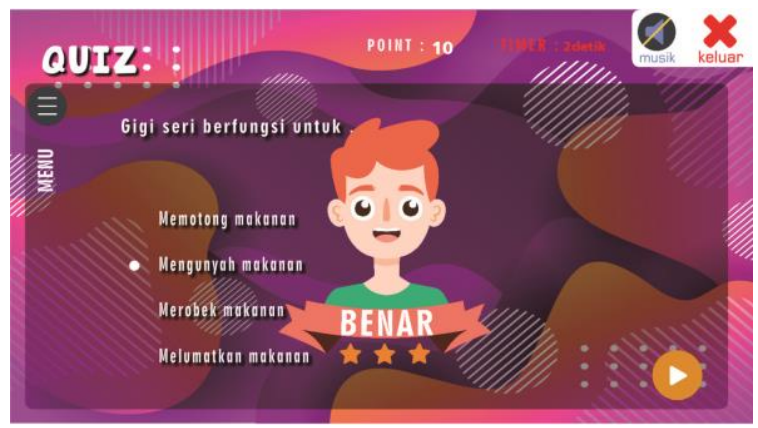

Gambar 14. Tampilan Soal Quiz Jawaban Benar

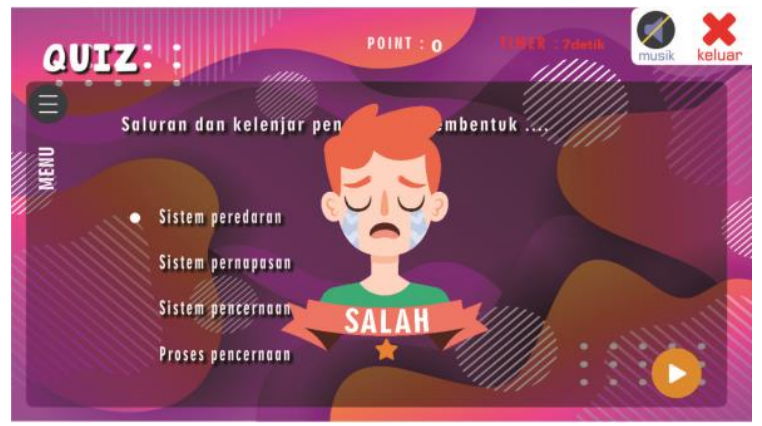

Gambar 15. Tampilan Quiz Jawaban Salah

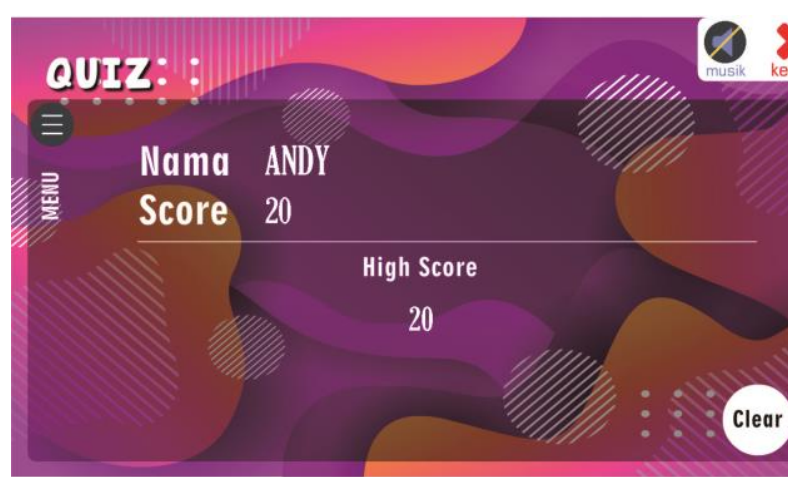

Gambar 16. Tampilan Hasil Quiz

e. Menu Simulasi

Menu simulasi adalah halaman yang berisi materi simulasi tentang proses makan pada tubuh, yang dikemas menggunakan simulasi gerak sederhana.

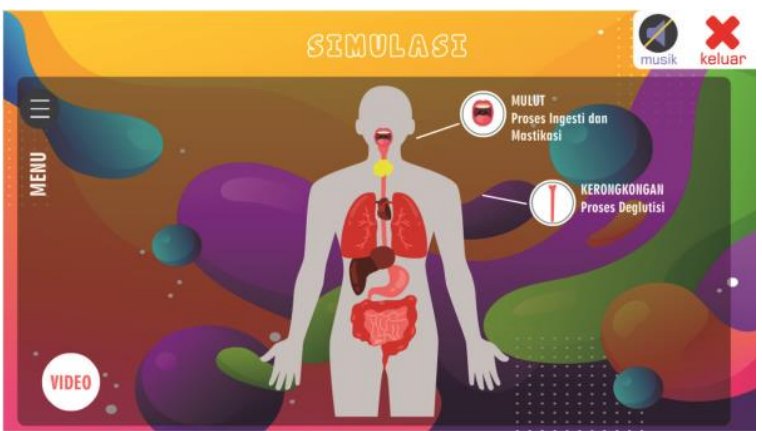

Gambar 17. Tampilan Menu Simulasi

f. Menu Game

Menu game merupakan game sederhana tebak kata yang berkaita dengan materi sistem pencernaan manusia

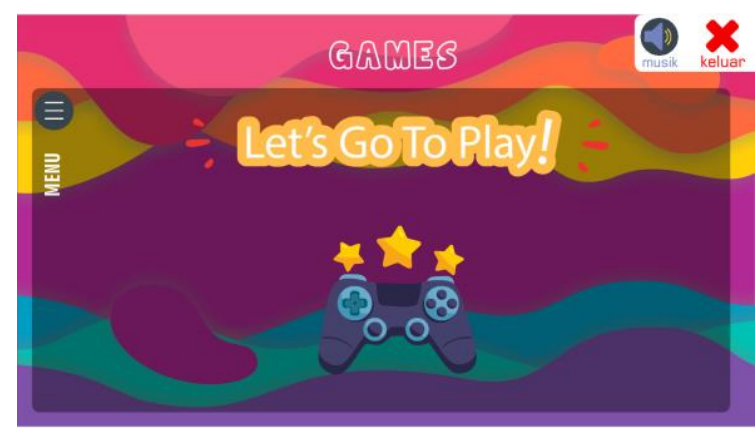

Gambar 18. Tampilan Menu Awal Game

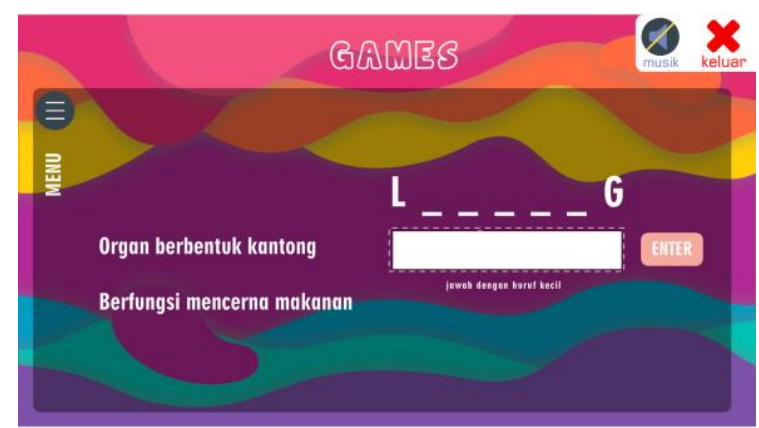

Gambar 19. Tampilan Soal Game

g. Menu Panduan

Menu panduan merupakan halaman yang berisi tentang petunjuk penggunaan aplikasi.

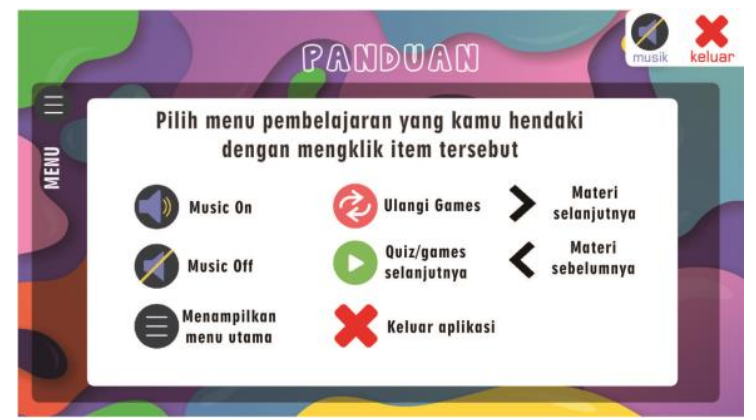

Gambar 20. Tampilan Menu Panduan 


\section{Testing}

Tahap testing dilakukan setelah selesai tahap implementasi dengan menjalankan aplikasi/program dapat dilihat apakah ada kesalahan atau tidak. Pada tahap ini, dilakukan pengujian menggunakan blackbox testing. Metode blackbox ini merupakan pengujian program berdasarkan fungsi dari program. Dari pengujian terakhir yang dilakukan dapat diperoleh hasil pengujian. Hasil pengujian dapat dilihat pada tabel dibawah ini.

Tabel 7. Hasil Blackbox Testing

\begin{tabular}{|c|c|c|c|}
\hline No & & Kegiatan testing & $\begin{array}{l}\text { Hasil } \\
\text { Pengujian }\end{array}$ \\
\hline 1. & $\begin{array}{l}\text { Imagel } \\
\text { Gambar }\end{array}$ & $\begin{array}{l}\text { Pengujian pada } \\
\text { gambar Background } \\
\text { aplikasi } \\
\text { Pengujian gambar } \\
\text { pada Buton aplikasi. } \\
\text { Pengujian pada } \\
\text { Image pendukung } \\
\text { aplikasi. }\end{array}$ & $\begin{array}{l}\text { Ok } \\
\text { Ok } \\
\text { Ok }\end{array}$ \\
\hline 2. & $\begin{array}{l}\text { Button/ } \\
\text { Tombol }\end{array}$ & $\begin{array}{l}\text { Pengujian pada } \\
\text { Button Materi. } \\
\text { Pengujian pada } \\
\text { Button Quiz. } \\
\text { Pengujian pada } \\
\text { Button Simulasi. } \\
\text { Pengujian pada } \\
\text { Button Game. } \\
\text { Pengujian pada } \\
\text { Button Panduan. } \\
\text { Pengujian pada } \\
\text { Button Profil. }\end{array}$ & $\begin{array}{l}\text { Ok } \\
\text { Ok } \\
\text { Ok } \\
\text { Ok } \\
\text { Ok } \\
\text { Ok }\end{array}$ \\
\hline 3. & Animasi & $\begin{array}{l}\text { Pengujian pada } \\
\text { animasi tampilan } \\
\text { Animasi simulasi. }\end{array}$ & $\begin{array}{l}\text { Ok } \\
\text { Ok }\end{array}$ \\
\hline 4. & Suara & $\begin{array}{l}\text { Pengujian pada suara } \\
\text { latar aplikasi. } \\
\text { Pengujian suara pada } \\
\text { Buton aplikasi. }\end{array}$ & $\begin{array}{l}\text { Ok } \\
\text { Ok }\end{array}$ \\
\hline
\end{tabular}

\section{KESIMPULAN}

A. Kesimpulan

Berdasarkan pembahasan diatas, maka dapat ditarik beberapa kesimpulan diantaranya sebagai berikut:

1. Aplikasi terdiri atas 6 menu utama yaitu menu materi yang terdiri atas 6 sub materi(rongga mulut, kerongkongan, lambung, usus halus, usus besar dan anus), menu quiz, menu simulasi, menu game, menu panduan dan menu profil sehingga aplikasi ini berhasil di rancang sesuai yang telah dibuat dan berhasil diterapkan pada perangkat android.

2. Dengan adanya aplikasi mobile media pembelajaran sistem pencernaan manusia dan gangguannya berbasis multimedia ini dapat membantu siswa lebih tertarik untuk belajar dan dapat lebih memahami pelajaran sistem pencernaan manusia.

3. Pembuatan Aplikasi mobile media pembelajaran sistem pencernaan dan gangguannya menggunakan adobe animate 2018 dapat mempermudah siswa dalam memperoleh alternatif sumber belajar sebagai penunjang pembelajaran dimana waktu dan tempat penggunaannya tidak harus di dalam kelas melainkan bisa diluar jam pembelajaran.

B. Saran

Berikut merupakan saran-saran untuk pengembangan lebih lanjut terhadap aplikasi mobile media pembelajaran sistem pencernaan manusia dan gangguannya berbasis multimedia, yaitu sebagai berikut:

1. Materi dalam aplikasi ini belum lengkap. Oleh karena itu, pengembangan lebih lanjut diharapkan untuk materi yang lebih lengkap.

2. Contoh gambar dan simulasi dalam aplikasi ini masih sedikit, jadi contoh selanjutnya diharapkan akan diberikan lebih lengkap.

3. Aplikasi ini hanya dapat diinstal pada perangkat android, diharapkan dalam pengembangan selanjutnya dapat dirancang dan diimplementasikan menjadi aplikasi open source.

4. Peneltian selanjutnya diharapkan agar dapat melihat potensi pengembangan media pembelajaran seperti ini pada bidang pendidikan. Sehingga peneliti selanjutnya dapat melakukan pengembangan pada mata pelajaran lainnya.

\section{DAFTAR PUSTAKA}

[1] M. I. P. Nasution, "Strategi Pembelajaran Efektif Berbasis Mobile Learning Pada Sekolah Dasar," J. Iqra', vol. 10, no. 01, pp. 1-14, 2016. R. S. Pressman, Rekayasa Perangkat Lunak: Pendekatan Praktisi Buku I. Yogyakarta: ANDI, 2015.

[3] A. Arsyad, Media Pembelajaran. Jakarta: PT. Raja Grafindo Persada, 2013.

[4] M. Fowler, UML Distilled. Tim Penerjemah Yogyakarta. Yogyakarta: ANDI, 2004.

[5] M. D. Irawan and S. A. Simargolang, "Implementasi E-Arsip Pada Program Studi Teknik Informatika," J. Teknol. Inf., vol. 2, no. 1, p. 67, 2018.

[6] I. Mustaqim and E. Prianto, "Modul Pelatihan Media Pembelajaran Adobe Flash," Fak. Tek. Univ. Negeri Yogyakarta, no. April, pp. 1-45, 2015.

[7] Kadaruddin, Mahir Desain Slide Presentasi dan Multimedia Pembelajaran Berbasis Powerpoint. Yogyakarta: Deepublish, 2018.

[8] Samsudin, "Perancangan Aplikasi Interactive Learning Berbasis Multimedia," J. Iqra', vol. 09, no. 01, pp. 126-142, 2015. 